\title{
Cidinha da Silva e o $O$ homem azul do deserto
}

Luiz Mauricio Azevedo da Silva ${ }^{1}$

A circulação da literatura de Cidinha da Silva se beneficia do recente aumento de interesse em relação à produção literária negra no Brasil contemporâneo. Contudo, seu texto sente os efeitos nocivos do enquadramento antropológico reducionista de sua obra, produzidos na esteira de nossos modismos étnico-literários. A operação em curso é simples: comemora-se a mera existência de sua produção porque representaria, per se, algum tipo de manifestação genuína da expressão artística negra, mas garante-se o vilipêndio crítico da referida obra. Trata-se, portanto, de uma cínica encenação de juízo. A presente resenha, é claro, não tem pretensão de desmontar essa complexa armadilha cultural, porém não pode se furtar a apontar a evidência dessa ausência e dela não participará.

Do ponto de vista estético - que é o que interessa aqui - há uma espécie de condução agressiva nas escolhas linguísticas da autora. Seus narradores estão sempre costurando o limite do traçado, beliscando a zebra, porque seus contos precisam chegar o mais perto possível das margens. Há uma evidente preocupação com a circulação dos textos, com a inteligibilidade deles para públicos eventualmente não-familiarizados com as rotinas de leitura.

O livro em questão é autoapresentado

como um conjunto de crônicas, embora o termo aqui apareça de um modo semanticamente inadequado. Atribui-se a esses textos, por engano, estratégia editorial ou desejo, a característica predominante de crônica. Trata-se de um erro conceitual. A crônica, como gênero, teve seu nascimento no seio dos periódicos impressos que emprestam ao autor seu prestígio, garantindo a ele um público burguês; e obrigando-o a respeitar um formato que exige, por imposição do espaço jornalístico, limite mínimo de

\footnotetext{
${ }^{1}$ Pós-doutorando no Departamento de Letras Clássicas e Vernáculas, USP.
} 


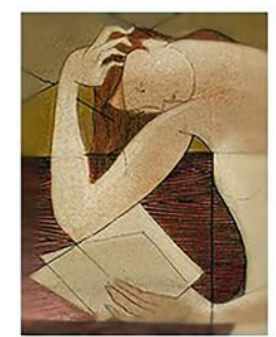

caracteres e uma certa profissionalização do olhar de quem escreve, que em alguns casos trágicos vira pasteurização estética.

Nada disso ocorre nesses textos. Os tamanhos são irregulares. As temáticas são múltiplas. E a autora conquista sozinha, jarda por jarda, seus leitores, fazendo de si mesma seu próprio veículo de divulgação. Nada está a seu lado. E nada está à sua disposição. O que Cidinha da Silva faz, ainda que talvez discorde disso, é conto. Conto no conceito específico de uma produção escrita, em que os acontecimentos individuais são alçados à categoria de miniaturizações da vida social. Nesse sentido, Cidinha da Silva torna a vida negra um artefato, sem que isso represente para o leitor uma redução do interesse estético de sua obra ao leitor amplo. É uma operação arriscada, como aliás é sua escrita. Ela, uma escritora afrodescendente com ampla presença no ambiente digital, é o fruto luminoso de um conjunto de lideranças do movimento negro que procuram escapar das definições apressadas indicadas por nossa literatura eurodescendente, em simulação da neutralidade objetiva.

Em “A janela e o passarinho", que abre o volume, há um flerte com o lirismo de Rubem Braga e a poética drummônica; mas, ao contrário das obras desses autores, a suavidade dá lugar à gravidade; e a confiança no poder revolucionário da classe trabalhadora é substituída pela realidade do triunfo da terceirização dos serviços, encarnada pela figura do motoboy, que sempre em risco, sempre com pressa, vive de se deslocar, de despermanecer, de surgir em lugares que não o querem (mas que dele necessitam) e surgir em lugares onde esperam o que ele transporta, mas rejeitam sua presença. O desfecho da narrativa (o enterro apressado de um pássaro por um motoboy) deveria representar algum tipo de imagem poética dissonante, que contrastasse com a rotina robótica da cidade, mas paradoxalmente não comove nossa mentalidade brasileira e expõe toda a crise de um país onde já não há mais espaço nem sequer para o insólito. Este texto contundente é uma boa forma de começar o livro e de apresentar as credenciais estéticas da mineira nascida em 1967. Outros que merecem destaque são "Dia das namoradas", "Zelador", "Você não vale nada, mas eu gosto de você" e "Viva, Winnie Mandela".

"Dia das namoradas" traz uma fratura extensa na expectativa heteronormativa. A começar pelo título e a estender-se pelos diálogos - que falam de funções domésticas 


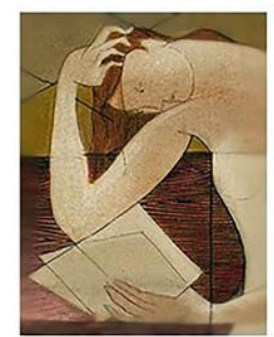

exercidas por mulheres nos moldes domésticos tradicionais - a história protesta contra as narrativas únicas que excluem outros modelos de relação erótico-afetivas, ao mesmo tempo em que abraça as limitações do formato burguês de relacionamento entre mulheres. A delícia do direito à vida em comum aparece, lado a lado, com a frustração e a monotonia dos papéis pré-estabelecidos da vida doméstica brasileira, em uma inteligente investigação sobre a repetição dos arquétipos sociais dominantes em certos hábitos contemporâneos dos indivíduos dominados.

Já em "Zelador", a questão da solidão da mulher negra, sempre tão em pauta nas mídias sociais, ganha aqui uma nova perspectiva. De certa maneira, até mesmo para pessoas em situação de subalternia social, às mulheres negras está interditado o direito à autogestão e ao uso independente de seu tempo livre. A elas é dado, pelo que se deixa antever no texto, o direito de trabalhar para alguém e o direito de estar à serviço de alguém. O personagem do zelador, recém-divorciado, acredita que na falta de filhos, homens e barulho, a vida da mulher negra é vazia e deve ser usufruída por ele, como uma espécie de serviço público de apoio.

Em "Você não vale nada, mas eu gosto de você", há uma interessante exploração do universo erótico da maturidade; e aparece mais uma ruptura: a da expectativa de desenlaces matrimoniais violentos, que a cultura do feminicídio nos oferta:

Os dois já eram um corpo só, ela na frente, ele atrás, desajeitados sobre a pia da cozinha. Alguém abre a porta da sala. Os meninos não eram. É tudo o que ele consegue pensar. Falta o ar, o chão. Falta tempo para raciocinar. Quando o marido vê a cena, grita sem surpresa: francamente, Dircinha, pensei que você já tivesse sossegado esse fogo no rabo! Mas com um paraíba? E pam! Pam! Bate a porta. ${ }^{2}$

A onomatopeia aí presente amplia ainda mais a ambiguidade do texto. Em uma chave interpretativa o primeiro pam pode ser fruto de uma tentativa de simulação eufemística do ato sexual. O segundo pam pode ser tanto o barulho de um disparo de arma de fogo quanto um golpe físico nos personagens. Já a batida de porta, por sua vez não elimina a possibilidade de um eventual duplo homicídio, como também não garante tal desfecho. Por fim, há ainda a exposição de um preconceito social, que vem à tona no momento de suposta suspensão das hierarquias sociais em função da imposição dos instintos básicos. Para se proteger do rebaixamento simbólico que a traição conjugal

\footnotetext{
${ }^{2}$ SILVA, Cidinha da. O homem azul do deserto. Rio de Janeiro: Malê, 2018. p. 51.
} 


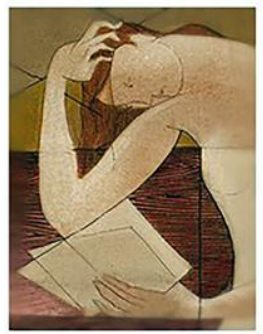

representa e devolver o arranhão na identidade íntima, o indivíduo recorre ao apelo do tecido cultural, procurando importar a hierarquia social na qual é privilegiado para dentro do flagrante da traição da qual é vítima.

Em Mario e a poética do amor, Silva desloca a polêmica das identidades de gênero para a interdição do direito ao amor, denunciando assim a existência de uma vergonhosa campanha de voyeurismo homofóbico, disfarçada de um bem-intencionado ajuste biográfico sobre os autores que nos formaram:

E é por configurar denso material humano que as cartas de Mário e seus segredos poderiam exercer fascínio. Porque o amor oferece sol de verão e sombra de copa grande ao mesmo tempo, água fresca, comida, perfume, canto de passarinho. Sim, o amor é também exigente, tira quem ama do centro, inverte o fogo, reclama atenção para as borboletas coloridas, telefona de madrugada, grita pedindo colo, grita ao gozar. Sim, o amor convulsiona a rotina, o esquema, o planejamento prévio. Contrapõe dinâmica à letargia. $\mathrm{O}$ amor traz saúde porque vira do avesso, põe os pés para cima e a cabeça para baixo. Desconfio que seja amor, aquele que sobrepõe a dor, a angústia e a amargura, o que encontrarão ao abrir as cartas de Mário. $^{3}$

No texto mais conhecido do livro, que tematiza o episódio em que a autora dividiu uma mesa de bar com a teórica afroamericana Angela Davis, a autora manipula a expectativa pueril dos leitores.

Mas o mais importante da noite ainda não contei. É que ao mudar-se de lugar, Angela Davis, que é muito alta, sentou-se numa cadeira maior do que as outras ou que estava num ponto mais alto da calçada. Fato é que a junção das duas coisas deixou-a em destaque na mesa. Ninguém reparou porque ela já era a grande estrela e era natural que a víssemos como a maior de todas. Mas ela, muito incomodada, falava como que para si mesma, que estava mais alta do que todo mundo e olhava para o chão e para os lados, buscando solução para o problema. Eu, pensando tratar-se da própria altura dela, disse que ela era mesmo a mais alta da mesa e ela respondeu "eu sei, mas tem alguma coisa errada aqui". Então, mais uma vez Angela se levantou e trocou de lugar, sentando-se na cadeira ao lado, mais baixa ou nivelada às demais pela calçada, ficando assim na mesma altura das demais pessoas. E disse aliviada: "Agora, sim! Agora eu estou confortável. ${ }^{4}$

Nesse texto Silva ataca o circuito de produção intelectual e as ambiguidades involuntárias da indústria cultural, que de um lado alimenta uma certa fetichização da personalidade de autor e por outro dificulta o exercício dela. A sensação que o leitor atento tem é que as estrelas finalmente desceram à terra, sendo muito difícil escapar da suspeita de que Silva coloca aqui, inteligentemente, Angela Davis como objeto de um sofisticado experimento adorniano. A insistência da autora afroamericana em ajeitar uma

\footnotetext{
${ }^{3}$ SILVA, Cidinha da. O homem azul do deserto. Rio de Janeiro: Malê, 2018. p.77.

${ }^{4}$ SILVA, Cidinha da. O homem azul do deserto. Rio de Janeiro: Malê, 2018. p. 64.
} 


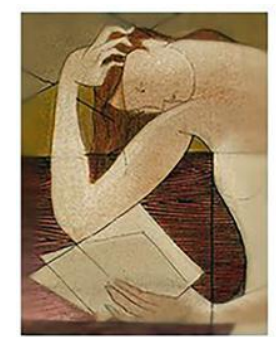

PPG-LET UFRGS
https://seer.ufrgs.br/NauLiteraria
V. 17, n.1 - 2020
Dossiê Literatura, Raça e Etnia

cadeira que a colocava em posição de comando é um reconhecimento a sua posição de intelectual consciente de seus deveres e compromissos, mas também uma crítica à sedução dos simbolismos militantes que podem causar desconforto justamente porque revelam aquilo que não queremos suportar.

Mostrar dois lados de uma mesma moeda é uma estratégia interpretativa que Silva leva ao limite em "Viva, Winnie Mandela", em que, à primeira vista, faz um resgate da figura da líder na luta contra o apartheid; mas em uma leitura mais profunda acaba por dar voz a uma parte egocêntrica de Winnie, que pode levar o leitor a concluir que a líder estava mais preocupada com o legado de sua própria luta do que com o êxito da causa libertária negra.

Silva sempre chama atenção para algo que parece surpreendente, distraindo-nos daquilo que não deseja que vejamos, porque assim - e somente assim - poderá entregar o que pretende. Seu leitor é cozido, lentamente, até que vire ele mesmo o produto de seu consumo. Ela é ora a autora bem sucedida, que vai em lugares que ninguém mais vai, ora é uma autora subestimada, que é obrigada a fazer o que nenhum par na posição dela é obrigado a fazer. Essa dicotomia intermitente é necessária para se compreender não apenas o trabalho da autora, mas o funcionamento da sociedade na qual se vive, onde aparecimento e desaparecimento se alternam ora revelando o que não merece ser visto, ora encobrindo o que deve ser revelado. O resultado é um conjunto de imagens distorcidas que não são fiéis às condições que as produziram. O trabalho de Cidinha da Silva é fazer os leitores engolirem outros espelhos, que possam operar, de dentro dos selfies, transformações não deformadoras. Trata-se, portanto, de uma literariedade sofisticada, com aparência de brutalismo, como é, aliás a melhor parte do modernismo brasileiro: a parte invisibilizada. 